\title{
The Antioxidant Activity of Ethanol and Methanol Extracts of Sesame meal by Ultrasonic Method in Comparison with the Synthetic Antioxidants in Iranian Mutton Tallow
}

\author{
MEHRI SOODBAR ${ }^{1}$, YOUSEF RAMEZAN ${ }^{\star 1}$ and PARVIN ESHRATABADI ${ }^{2}$
}

\author{
'Department of Food Sciences \& Technology, Faculty of Advanced Sciences \& Technology, \\ Pharmaceutical Sciences Branch, Islamic Azad University, Tehran, Iran. \\ ${ }^{2}$ Institute of Standards and Industrial Research of Iran Karaj, Iran. \\ ${ }^{*}$ Corresponding author E-mail: y.ramezan@yahoo.com \\ http://dx.doi.org/10.13005/ojc/320231
}

(Received: February 09, 2016; Accepted: March 25, 2016)

\begin{abstract}
Sesame seeds and its compounds are resistance to oxidative deterioration owing to their natural antioxidants, such as sesamin, sesamolin, sesamol, sesaminol and their glucosides. The purpose of this research is to extract sesame ethanol and methanol antioxidant compounds as by-products by ultrasonic method, then identified by HPLC and has been compared with synthetic antioxidants BHA, BHT, TBHQ on mutton tallow. Ethanolic and methanolic extracts which were extracted by ultrasonic and synthetic antioxidants at concentrations of $0,50,100$ and $200 \mathrm{mg} / \mathrm{kg}$ were applied on mutton tallow. The results of the oxidative stability based on Rancimat apparatus, Rancimat was operated at $110^{\circ} \mathrm{C}$ with an air flow of $18-20 \mathrm{~L} / \mathrm{h}$ and measures the induction period (IP) of the selected samples, showed that ethanolic and methanolic extracts of sesame meal at concentrations of 100 and $200 \mathrm{mg} / \mathrm{kg}$ are not much different from BHT at 50 and $100 \mathrm{mg} / \mathrm{kg}$ concentrations and also from the methanolic extractat $200 \mathrm{mg} / \mathrm{kg}$ concentration in terms of oxidative stability, behave similarly to $50 \mathrm{mg} / \mathrm{kg}$ concentration of BHA. The results show that the natural antioxidants can be the perfect alternative to synthetic antioxidants.
\end{abstract}

Keywords: Antioxidants, Mutton Tallow,Oxidative Rancidity, Sesame meal, Sesamin.

\section{INTRODUCTION}

The oxidative deterioration of lipids causes rancid odors and flavors as well as the formation of secondary compounds. Products derived from lipid oxidation causes early aging, heart disease, cancer and membrane damage that can be considered as threats to human health. The additional result of antioxidants is an essential way to preserve oxidation of fats and oils in food. Although reports illuminate that synthetic antioxidants that are used as additives in edible oils can be toxic, and increases manufacturing costs and has Hazardous effects on human health and lower efficacy of natural antioxidants. The replacement of synthetic antioxidants by natural antioxidants 
may have effects due to health implication,therefore demands for usage of natural antioxidants in food system have been enlarged ${ }^{1,2,3}$.

There are many assumptions due to the safety of natural antioxidants so attentions turned to use plant seeds such as sesame regarding to their high content of unsaturated fatty acids, vegetable protein, soluble fiber, flavonoids and other compounds, which have antioxidant activity ${ }^{4}$.

Table 1: Natural And Synthetic Antioxidant Activity Obtained By Rancimat Apparatus (H)

\begin{tabular}{lc}
\hline Sample & Induction Period \\
$(\mathrm{mg} / \mathrm{kg})$ & (h) \\
\hline
\end{tabular}

\begin{tabular}{|c|c|}
\hline mutton tallow oil & $4.25 \pm 0.247^{m}$ \\
\hline $\begin{array}{l}\text { mutton tallow oil + } 50 \\
\mathrm{mg} / \mathrm{kg} \mathrm{BHA}\end{array}$ & $12.1 \pm 0.863^{h}$ \\
\hline $\begin{array}{l}\text { mutton tallow oil + } 100 \\
\mathrm{mg} / \mathrm{kg} \mathrm{BHA}\end{array}$ & $18.47 \pm 0.092^{\mathrm{g}}$ \\
\hline $\begin{array}{l}\text { mutton tallow oil }+200 \\
\mathrm{mg} / \mathrm{kg} \mathrm{BHA}\end{array}$ & $19.04 \pm 0.304^{\mathrm{fg}}$ \\
\hline $\begin{array}{l}\text { mutton tallow oil + } 50 \\
\mathrm{mg} / \mathrm{kg} \mathrm{BHT}\end{array}$ & $7.93 \pm 0.042^{\mathrm{jkl}}$ \\
\hline $\begin{array}{l}\text { mutton tallow oil + } 100 \\
\mathrm{mg} / \mathrm{kg} \mathrm{BHT}\end{array}$ & $9.35 \pm 0.007^{\mathrm{jk} k}$ \\
\hline $\begin{array}{l}\text { mutton tallow oil }+200 \\
\mathrm{mg} / \mathrm{kg} \mathrm{BHT}\end{array}$ & $11.43 \pm 1.011^{\mathrm{hi}}$ \\
\hline $\begin{array}{l}\text { mutton tallow oil + } 50 \\
\mathrm{mg} / \mathrm{kg} \mathrm{TBHQ}\end{array}$ & $20.94 \pm 1.633^{\dagger}$ \\
\hline $\begin{array}{l}\text { mutton tallow oil + } 100 \\
\mathrm{mg} / \mathrm{kg} \text { TBHQ }\end{array}$ & $29.39 \pm 0.849^{e}$ \\
\hline $\begin{array}{l}\text { mutton tallow oil + } 100 \\
\mathrm{mg} / \mathrm{kg} \mathrm{TBHQ}\end{array}$ & $34.79 \pm 0.643^{d}$ \\
\hline $\begin{array}{l}\text { mutton tallow oil + } 50 \text { mg/kg } \\
\text { ethanolic ultrasonic extract }\end{array}$ & $6.75 \pm 0.325$ \\
\hline $\begin{array}{l}\text { mutton tallow oil + } 100 \mathrm{mg} / \mathrm{kg} \\
\text { ethanolic ultrasonic extract }\end{array}$ & $7.28 \pm 0.78^{\mathrm{kl}}$ \\
\hline $\begin{array}{l}\text { mutton tallow oil }+200 \text { mg/kg } \\
\text { ethanolic ultrasonic extract }\end{array}$ & $7.42 \pm 0.106^{\mathrm{kl}}$ \\
\hline $\begin{array}{l}\text { mutton tallow oil + } 50 \text { mg/kg } \\
\text { methanolic ultrasonic extract }\end{array}$ & $6.83 \pm 0.445$ \\
\hline $\begin{array}{l}\text { mutton tallow oil + } 100 \text { mg/kg } \\
\text { methanolic ultrasonic extract }\end{array}$ & $7.47 \pm 0.12^{\mathrm{jkl}}$ \\
\hline $\begin{array}{l}\text { mutton tallow oil + } 200 \text { mg/kg } \\
\text { methanolic ultrasonic extract }\end{array}$ & $9.85 \pm 0.12^{h i j}$ \\
\hline
\end{tabular}

Sesame seed (Sesamum indicum) is recognized as a source of high activity antioxidant with tocopherol and lignans as primary compounds. Sesame is one of the most edible oil seeds which had been used through East Africa where it is generally grown for grain and oil. The chemical composition of sesame indicated that the seed is a significant source of oil (44 - 58\%), protein (18 - 25\%), carbohydrate $(\sim 13.5 \%)$ and ash $(\sim 5 \%)^{5,6}$.

Due to the sesame seed's considerable amount of nutrients, including protein, essential fatty acids, vitamin E, minerals and lignans(including sesamin, sesamolin, and sesaminol) has special significance in terms of nutrition and low production cost. Its lignans may have antioxidants and antiinflammatory properties ${ }^{4,7}$.

Sesame seed oil significantly shows high resistance against autoxidation and also avoids the oxidation of linoleic acid. These antioxidants have no color, taste and odor at low concentrations in comparison with synthetic antioxidants such as $\mathrm{BHA}$ and $\mathrm{BHT}$ in small amounts ${ }^{8,9}$.

Sesame seed naturally contains lignans and lignan-glucosides as the functional components which are mainly related to its antioxidant's properties. The major lignans in sesame seed are sesamin and sesamolin that are progressively improved to two phenolic antioxidants, sesaminol and sesamol ${ }^{9,10}$.

Sesamin and sesamol in compounds are higher in oil soluble lignan compounds in compare with other lignan values. Sesamin makes up more than half of the lignan contained compounds. These compounds function in controlling lipid metabolism, lowering cholesterol, enhancing hepatic fatty acid oxidation enzymes, protecting patients against brain disorders and have medicinal properties. They are also anticancer and antioxidant ${ }^{11,12,13}$.

In this study, sesame seeds'meal as byproduct of the oil industry, isused for the extraction of sesame seeds' antioxidants. In these circumstances, phenolic compounds, radical inhibitory activity, power reduction's effect and antioxidant activity of sesame meal are significantly increased ${ }^{14,15}$. 
The research made an effort to use sesame meal for extracting natural antioxidants and use its ability to compare antioxidants activity with synthetic antioxidants.

\section{MATERIALS AND METHODS}

Sesame meal samples which were used in this study were provided from a store in a local market that is working in a line with sesame oil production. Also Iranian mutton tallow that is aimed in the study was consumed in a local market in Tehran. Defatted sesame meal was powdered by mortar and then it was used in next steps of extractions. The standard of sesamol was obtained from Sigma Chemical Co. (St. Louis, MO, USA), and all solvents were of HPLC or analytical grade (Merck).

\section{Standards preparation}

Stock solutions of sesame compounds (2 $\mu \mathrm{g} / \mathrm{mL}$ ) were prepared in methanol, which was stable for weeks in the dark and at $0^{\circ} \mathrm{C}$. The stocks were used for the preparation of working standards $(0.05$, $0.1,0.2,0.3,0.4,0.5 \mu \mathrm{g} / \mathrm{mL})$ and calibration curve.

\section{Extraction by Ultrasonic Bath}

$400 \mathrm{ml}$ of ethanol and methanol was poured throw $300 \mathrm{~g}$ of sesame meal powder predicated in an ultrasonic bath with room temperature for 45 minutes, degassing operations were done at the frequency of $60 \mathrm{~Hz}$. Degassing process of extracting, facilitated the extraction of phenolic compounds during the ultrasound.

\section{Identification of extracted compounds by HPLC}

The method was based on direct extraction of polar biophenol compounds of sesame meal by using solutions of ethanol and methanol that had been detected by HPLC with $280 \mathrm{~nm}$ UV. Three solvents were used for the washing gradient, such as, water containing $0.2 \%$ phosphoric acid (V/V), methanol and acetonitrile. Washing solutions had to be degassed ${ }^{6}$.

Incorporation of antioxidant compounds with Iranian mutton tallow to evaluate oxidative stability

The synthetic antioxidants butylated hydroxyanisole (BHA), butylated hydroxytoluene (BHT)and Tertiary butylhydroquinone(TBHQ), ethanolic and methanolic extracts were applied on the mutton tallow that obtained by ultrasonic extraction methods at concentrations of $0,50,100$ and $200 \mathrm{mg} / \mathrm{kg}$, until evaluation was started.

\section{Rancimat analysis}

The induction period of the samples were evaluated by Metrohm Rancimat apparatus model 743(Herisau / Switzerland). The instrument was

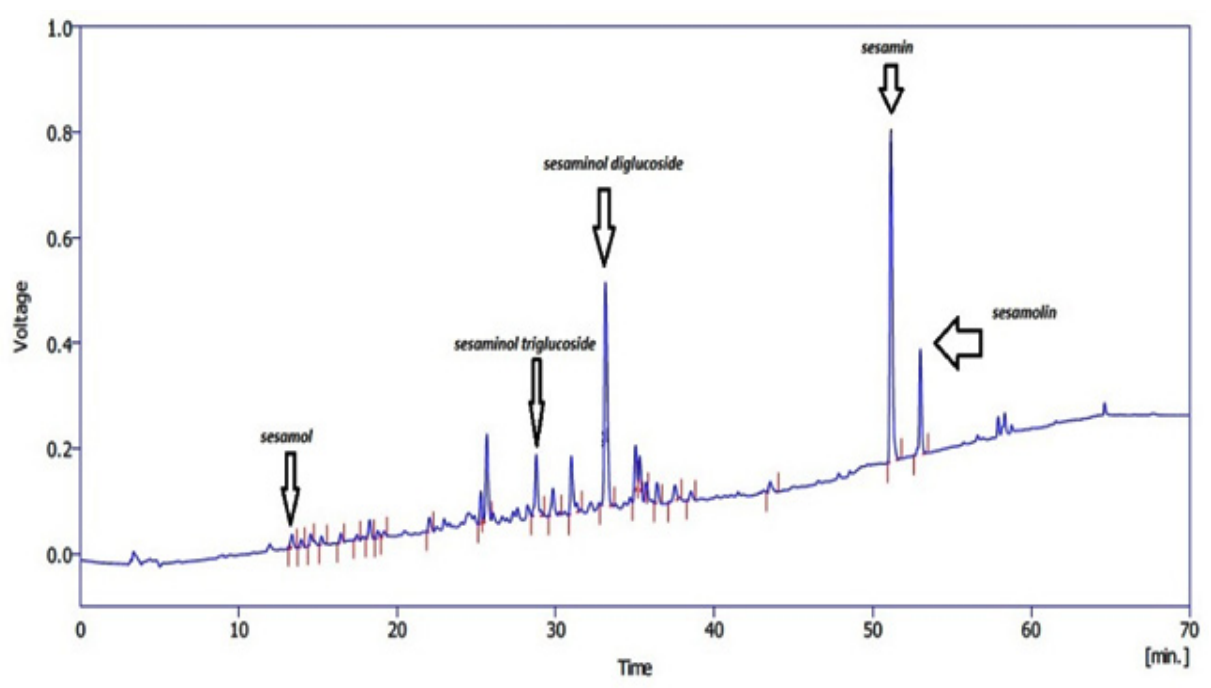

Fig.1: chromatogram of the ethanolic extraction of antioxidants by Ultrasonic extraction method 
operated at $110^{\circ} \mathrm{C}$ with an air flow rate of $18-20 \mathrm{~L} / \mathrm{h}$. The induction period was recognized by a sharp change in the slope on the chart. A tangent was drawn from the slope to intersect an extension of the base line and the distance of this intersection was a measure of the induction time from the start ${ }^{17}$.

\section{Statistical analysis}

The data were analyzed by using a complete randomized design. To determine significant data, one-way experiments (ANOVA) were used. The Tukey's test was applied to compare means at 5 percent by using Minitab 16 software. All results are the consequences of \pm standard deviation and were performed for at least 3 times.

\section{RESULTS AND DISCUSSIONS}

The results of HPLC identification of antioxidant extracts from ethanolic and methanolic sesame meal extract by ultrasonic bath extraction method are shown in Fig.1 and Fig.2. It is observed that ethanolic and methanolic sesame meal antioxidant extracts by ultrasonic bath extraction method were evaluated and the natural antioxidants viz sesamol, sesaminol T-glucoside, sesaminol D-glucoside, sesamin and sesamolin were identified respectively.

Iranian mutton tallow oxidative stability evaluation was conducted by Rancimat apparatus.
Table 1 are presented oxidative stability of Iranian mutton tallow incorporation with synthetic antioxidants, ethanolic and methanolic antioxidant extracts obtained from the ultrasonic bath extraction method which were added into mutton tallow, at concentrations of $0,50,100$ and $200 \mathrm{mg} / \mathrm{kg}$.

\section{DISCUSSIONS}

Most researchers have been attributed not able oxidative stability of sesame seed oil to non-saponification substances to date. In this study, oxidative stability of Iranian mutton tallow with ethanolic and methanolic antioxidant extracts obtained by ultrasonic bath extraction techniques were compared with synthetic antioxidants at concentrations of $0,50,100$ and $200 \mathrm{mg} / \mathrm{kg}$ at $110^{\circ} \mathrm{C}$ by Rancimat apparatus.

Suja et al.(2004)stated that applying sesame meal extract at 5, 10, 50 and $100 \mathrm{mg} / \mathrm{kg}$ concentrations in soybean, sunflower and safflower oil during storage, increased oils' oxidative stability. The obtained antioxidant extracts, had a higher impact on oxidative stability than BHT at $200 \mathrm{mg} /$ $\mathrm{kg}^{18}$.

Mohdaly et al. (2011) and Abdelazim et al.(2013) reported an assessment between the antioxidant activity of the sesame meal extracts and synthetic antioxidants on vegetable oils. So there

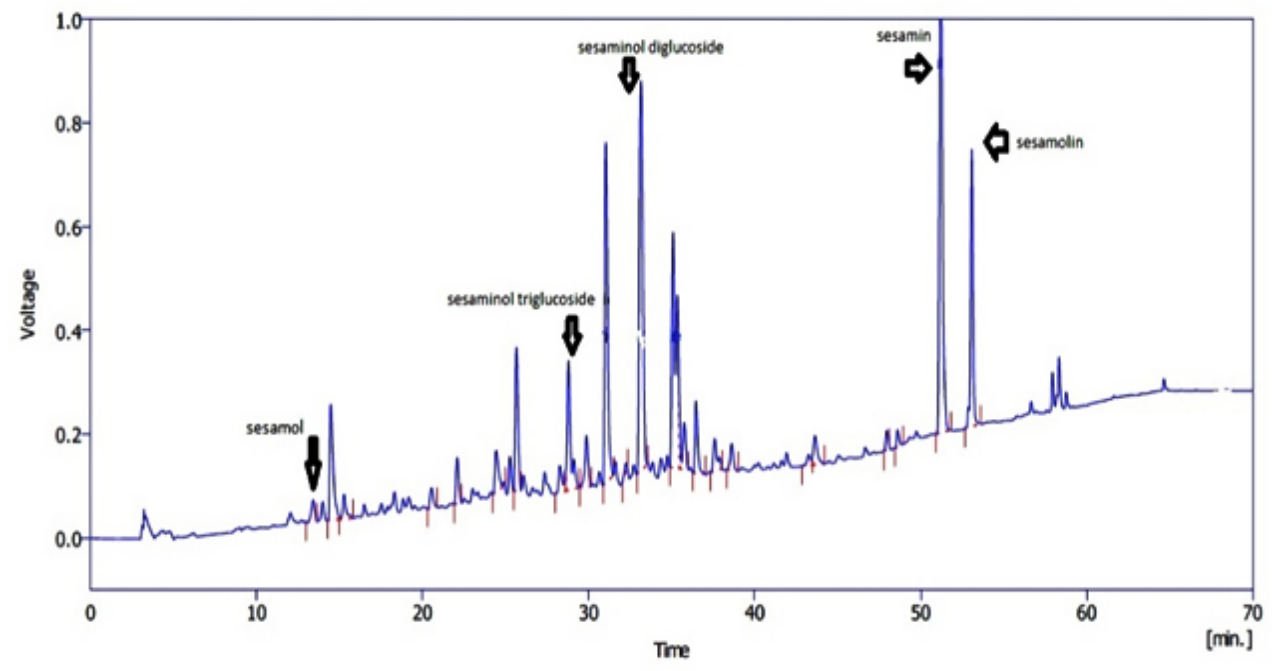

Fig. 2: chromatogram of the methanolic extraction of antioxidants by Ultrasonic extraction method 
were similarities between the results of this study and their studies about antioxidant activity of the sesame meal extracts and synthetic antioxidants on the mutton tallow and on vegetable oils' oxidative stability ${ }^{19,20}$.

In the present work, there is no significant difference $(P>0.05)$ between oxidative stability of mutton tallow at 50 and $100 \mathrm{mg} / \mathrm{kg}$ of $\mathrm{BHT}$ and $100 \mathrm{mg} / \mathrm{kg}$ of ethanolic and methanolic antioxidant extracts gained from the ultrasonic bath method.

Oxidative stability significantly lowers the induction time $(P<0.05)$, at $50 \mathrm{mg} / \mathrm{kg}$ ethanolic and methanolic extracts obtainedby ultrasonic bath extraction technique, in comparison with $\mathrm{BHT}$ at $100 \mathrm{mg} / \mathrm{kg}$ concentration. However, no significant difference was observed at concentration of $50 \mathrm{mg} / \mathrm{kg}$ of ethanolic and methanolic antioxidant substances extracted by ultrasonic bath method and BHT (P>0.05).

It was observed that the methanolic extract obtained by ultrasonic bath extraction method at concentration of $200 \mathrm{mg} / \mathrm{kg}$, behaved like $50 \mathrm{mg} / \mathrm{kg}$ concentration of BHA. Also there were no significant differences between the concentrations of $100 \mathrm{mg} /$ $\mathrm{kg}$ methanolic extract with other concentrations of methanolic extract. TBHQ is the most efficient antioxidant followed by $\mathrm{BHA}, \mathrm{BHT}$, methanolic and ethanolic extracts, in decreasing order.

\section{CONCLUSION}

According to the results obtained in this study, it can be stated that these natural antioxidants have the ability to substitute the synthetic antioxidants or whether synthetic antioxidants can be used with natural antioxidant to increase the stability of lipid rancidity against autoxidation process in food industry.

\section{ACKNOWLEDGMENT}

The authors are grateful to Institute of National Iranian Standards and Industrial Research for their technical assistance with sample extractions, HPLC and Rancimat analysis in this study.

\section{REFERENCES}

1. Fahimi,R.; Elhamirad, A.H.; Hadad Khodaparast, M.H.; Estiri, S.H.; Armin,M.; Askari,B.; Mokhtari, F.; Ghasemi, S. National Food Science Congress. 2011.

2. Konsoula, Z.; Liakopoulou-Kyriakides, M. LWTFood Sci. Technol. 2010, 43, 1379-1386.

3. Moure, A.; M.Cruz, J.; Franco, D.; Dominguez, J.M.; Sineiro, J.; Dominguez, H.; Nunez, M J.; Parajo, J.C. Food Chem. 2001, 72, 145-171.

4. Ghani, N. A.; Shawkat, M. S.; Umran, M. A. Current Res. J. Biol. Sci. 2012, 4, 159-163.

5. Fitrotin, U.; Utami, T.; Hastuti, P.; Santoso, U. Int. J. Biol. Sci. 2015, 4, 56-61.

6. Rizki, H.; Kzaiber, F.; Nablousi, A.; Elharfi, M.; Ennahli, S.; Hanine, H. Int. j. adv. res. sci. eng. technol.2015, 2, 392-397.

7. Khadem Haghighi, M.; Alipoor, B.; Malek Mahdavi, A.; Eftekhar Sadat, B.; Jafarabadi, M.; Moghadam, A. 2014. Acta med. Iran. 2014, 53, 207-213.

8. Suja, K.P.;Jayalekshmy, A.; Arumughan, C. Food Chem. 2005,91, 213-219.
9. Ramezan, Y.; Ghavami, M.; Bahmaei, M.; Givianrad, M. H.;Hemmasi, A. H. (2015). Orient. J. Chem. 2015,31(3), 1389-1394.

10. Chakraborthy, G.S.; Sharma, G.; Kaushik, K. N. J. Herb. Med. Toxic.2008,2, 15-19.

11. Rangkadilok, N.; Pholphana, N.; Mahidol,C.; Wongyai, W.; Saengsooksree, K.; Nookabkaew, S.; Satayavivad, J. Food Chem. 2010, 122, 724-730.

12. Shirato-Yasumoto, S.; Komeichi, M.; Okuyama, Y.; Horigane, A. Sabrao J. Breed. Genet. 2003, 35, 27-34.

13. Zhou, J-C.; Feng, D-W.; Zheng,G-S. J. Food Eng. 2010, 100, 289-293.

14. Hassan, M.A. 2013. World J. Dairy Food Sci. 2013, 8, 51-57.

15. Elleuch, M.; Besbes, S.; Roiseux, O.; Blecker, C.; Attia, H. Food Chem. 2007, 103, 641-650.

16. COI/T.20/Doc No 29. 2009. Determination of biophenols in olive oils by HPLC.

17. ISO6886. 2006. Animal and vegetable fat and oil- determination of oxidative stability 
(accelerated oxidation method).

18. Suja, K.P.; Abraham, J.T; Thamizh, S.N, Jayalekshmy, A.; Arumughan, C. Food Chem. 2004, 84, 393-400.

19. Abdelazim, A.; Mahmoud, A.; Ramadan-
Hassanien, M.F. Food Sci. Techno.2013,50, 868-878.

20. Mohdaly, A.A.; Smetanskaa, I.; Ramadan, M.F; Sarhan, M.A.; Mahmoud., A. Ind. Crop. Prod. 2011, 34, 952- 959 